Kent - 1

\title{
Association of Covert Cerebrovascular Disease Identified Using Natural Language Processing and Future Dementia
}

David M Kent ${ }^{1}$, MD, MS, Lester Y Leung ${ }^{2}$, MD, MSc, Yichen Zhou ${ }^{3}$, MS, Patrick H Luetmer ${ }^{4}, \mathrm{MD}$, David F Kallmes ${ }^{4}$, MD, Jason Nelson ${ }^{1}, \mathrm{MS}$, Sunyang $\mathrm{Fu}^{5}$, PhD, Chengyi Zheng $^{6}$, PhD, Hongfang Liu ${ }^{5}$, PhD, Wansu Chen ${ }^{6}, \mathrm{PhD}$

${ }^{1}$ Predictive Analytics and Comparative Effectiveness Center, Tufts Medical Center, Boston, MA, USA

${ }^{2}$ Department of Neurology, Tufts Medical Center, Boston, MA, USA

${ }^{3}$ Prior affiliation: Department of Research and Evaluation, Kaiser Permanente Southern

California, Pasadena, CA, USA; Current affiliation: AIML, Fractal Analytics, Inc

${ }^{4}$ Department of Radiology, Mayo Clinic, Rochester, MN, USA

${ }^{5}$ Department of Al and Informatics, Mayo Clinic, Rochester, MN, USA

${ }^{6}$ Department of Research and Evaluation, Kaiser Permanente Southern California, Pasadena, CA, USA

\section{Financial support and conflict of interest disclosure:}

This work was funded by a National Institutes of Health (NIH) grant (R01-NS102233).

The funder had no role in the design/conduct of the study, manuscript preparation, or decision to publish. The authors report no competing interests.

\section{Reprints and correspondence:}


medRxiv preprint doi: https://doi.org/10.1101/2022.02.09.22270682; this version posted February 10, 2022. The copyright holder for this preprint

(which was not certified by peer review) is the author/funder, who has granted medRxiv a license to display the preprint in perpetuity.

It is made available under a CC-BY-NC-ND 4.0 International license.

Kent - 2

David Kent, MD, MS

Director, Predictive Analytics and Comparative Effectiveness (PACE) Center

Institute for Clinical Research and Health Policy Studies

Tufts Medical Center

800 Washington St, Box 63

Boston, MA 02111

dkent1@tuftsmedicalcenter.org

ORCID ID: 0000-0002-9205-5070

Abstract: 299

Main Text: 3395

Tables: 3

Figures: 2

References: 37 
Kent - 3

\section{ABSTRACT}

Objective: To estimate the risk of dementia associated with incidentally-discovered covert cerebrovascular disease (CCD), including both covert brain infarction (CBI) and white matter disease (WMD).

Patients and Methods: We included individuals aged $\geq 50$ years enrolled in the Kaiser Permanente Southern California health system receiving a head CT or MRI for a nonstroke indication from January 1, 2009 and December 31, 2019, without prior ischemic stroke, transient ischemic attack, hemipelegia, hemiparesis, dementia/Alzheimer's disease or a visit reason / scan indication suggestive of cognitive decline. Using natural language processing (NLP), we identified the presence of CBI and WMD on the neuroimage report; WMD was characterized as mild, moderate, severe, or undetermined.

Results: Among 241,050 qualified individuals, NLP identified 69,931 (29.0\%) with WMD and 11,328 (4.7\%) with CBI. The dementia incidence rates (per 1,000 person-years) were $23.5(95 \% \mathrm{Cl} 22.90$ to 24.0$)$ for patients with WMD; 29.4 (95\% Cl 27.9 to 31.0$)$ with $\mathrm{CBI}$ and 6.0 (5.8 to 6.2) without CCD. The effect of WMD on dementia risk was stronger in younger versus older patients and for CT- versus MRI-discovered lesions. For patients with versus without WMD on CT scan, the adjusted HR (aHR) was 2.87 (2.58 to 3.19$)$ for those $<$ age 70 and 1.87 (1.79 to 1.95$)$ for those $\geq$ age 70 . For patients with versus without WMD on MRI, the aHR for dementia risk was 2.28 (1.99 to 2.62) for patients < age 70 and 1.48 (1.32 to 1.66) for those $\geq$ age 70 . The aHR associated with $\mathrm{CBI}$ was 2.02 (1.70 to 2.41 ) for patients age $<70$ and 1.22 (1.15 to 1.30$)$ for patients age 
medRxiv preprint doi: https://doi.org/10.1101/2022.02.09.22270682; this version posted February 10, 2022. The copyright holder for this preprint (which was not certified by peer review) is the author/funder, who has granted medRxiv a license to display the preprint in perpetuity. It is made available under a CC-BY-NC-ND 4.0 International license.

Kent - 4

$\geq 70$ for either modality. Dementia risk with WMD was strongly correlated with WMD severity.

Conclusion: Incidentally-discovered CCD is common and identifies patients at high risk of dementia, representing an opportunity for prevention. 
medRxiv preprint doi: https://doi.org/10.1101/2022.02.09.22270682; this version posted February 10, 2022. The copyright holder for this preprint

(which was not certified by peer review) is the author/funder, who has granted medRxiv a license to display the preprint in perpetuity.

It is made available under a CC-BY-NC-ND 4.0 International license.

Kent - 5

\section{ABBREVIATIONS}

CBI: covert brain infarction

CCD: covert cerebrovascular diseases

Cl: confidence intervals

CT: computer tomography

HR: hazard ratio

KPSC: Kaiser Permanente Southern California

NLP: natural language processing

WMD: white matter disease 
medRxiv preprint doi: https://doi.org/10.1101/2022.02.09.22270682; this version posted February 10, 2022. The copyright holder for this preprint

(which was not certified by peer review) is the author/funder, who has granted medRxiv a license to display the preprint in perpetuity.

It is made available under a CC-BY-NC-ND 4.0 International license .

Kent - 6

\section{INTRODUCTION}

Cardiovascular risk factors contribute to the development of several common forms of dementia and are a focus of efforts to prevent these diseases. ${ }^{1,2}$ Identifying high-risk individuals before the onset of severe cognitive decline is a central goal in dementia prevention research. One potentially appealing strategy is to identify individuals with covert cerebrovascular diseases (CCD), comprising both covert brain infarction (CBI) and white matter disease (WMD), which are known to be associated with an increased risk for dementia in cohort studies with participants undergoing screening by protocoldriven neuroimaging. ${ }^{3-10}$

However, building upon insights from screened cohort studies and translating their findings into real-world clinical practice has unique challenges. Findings from population-based research with protocol-driven magnetic resonance imaging (MRI) screening may not be generalizable to real-world cohorts which include only patients selected for clinically-indicated neuroimaging, where imaging may be dominated by computer tomography $(\mathrm{CT})$ scans and where neuroimaging interpretation and reporting are heterogeneous and poorly standardized. ${ }^{11,12}$ Yet studying incidentally-discovered CCD is impeded by the poor clinical documentation of these lesions; there are no ICD-9 codes for $\mathrm{CBI}$ or WMD and no ICD-10 codes for CBI. Additionally, these lesions are rarely documented in a patient's problem list even when they are reported on neuroimaging reports. Given these barriers to identifying patients with CCD, it is unsurprising that no current standard of care for the management of these conditions or 
medRxiv preprint doi: https://doi.org/10.1101/2022.02.09.22270682; this version posted February 10, 2022. The copyright holder for this preprint

(which was not certified by peer review) is the author/funder, who has granted medRxiv a license to display the preprint in perpetuity.

It is made available under a CC-BY-NC-ND 4.0 International license.

Kent - 7

evidence-based strategies for prevention of dementia following their discovery exists, despite the fact that they are commonly encountered in routine care. ${ }^{13}$

To facilitate identification of individuals with incidentally discovered CCD, we previously developed a Natural Language Processing (NLP) algorithm identifying these conditions with a high degree of accuracy. ${ }^{14,15}$ In this study, we port the NLP algorithm into Kaiser Permanente Southern California (KPSC), a large integrated health care system, to examine the prognostic significance of NLP-identified, incidentally-discovered CCD on risk of dementia.

\section{METHODS}

\section{Environment}

In this retrospective cohort study, we utilized health plan enrollees of KPSC, an integrated health care organization that serves 4.8 million individuals (approximately $19 \%$ of the region's population) at 15 hospitals and $230+$ medical offices, broadly representative of the residents in the region. ${ }^{16}$ Data was extracted, via a research data warehouse, from KPSC's electronic health record (EHR). This system integrates all aspects of care, including inpatient, emergency department, outpatient, pharmacy, and lab services, as well as billing and claims. The study protocol was approved by Tufts Medical Center's and KPSC's Institutional Review Board, which waived the need for informed consent.

\section{Population}


medRxiv preprint doi: https://doi.org/10.1101/2022.02.09.22270682; this version posted February 10, 2022. The copyright holder for this preprint (which was not certified by peer review) is the author/funder, who has granted medRxiv a license to display the preprint in perpetuity. It is made available under a CC-BY-NC-ND 4.0 International license .

Kent - 8

We included individuals age $\geq 50$ years enrolled in the KPSC health system who received head neuroimaging (CT, MRI) for a non-stroke indication between 2009-2019 and who had no history of ischemic stroke or dementia/Alzheimer's. Patients with transient ischemic attack (TIA), hemiplegia and hemiparesis and other medication conditions were also excluded to ensure a stroke- and dementia-free cohort.

Supplement A1 includes the complete ICD-9/ICD-10/CPT codes used to exclude patients. For the current analysis, we additionally excluded patients with a visit reason or scan indication suggestive of cognitive symptoms or decline (e.g. confusion, disorientation, altered mental status, or dementia evaluation).

If there were multiple neuroimaging studies, the first was considered the index scan. For neuroimaging evidence of cerebral infarction to be considered "covert," individuals were only included in the study if they did not acquire a new ICD code for a diagnosis of cerebral infarction or dementia within 60 days after the index scan. Patients who were not actively enrolled in the KPSC health plan on the index date or not continuously enrolled in the prior 12 months were also excluded (a gap of $\leq 45$ days was allowed).

\section{Identification of patients with CCD}

An NLP algorithm developed at Mayo Clinic and Tufts Medical Center was applied to neuroimaging reports associated with these index scans to identify individuals with documented $\mathrm{CBI}$ or WMD. ${ }^{14}$ As described in prior work, these algorithms adopted the open-source NLP pipeline MedTagger for generic NLP processing and task-specific knowledge engineering (coding of specific words and phrases referencing $\mathrm{CBI}$ and WMD) to yield identification of $\mathrm{CBI}$ and WMD that was on par with human readers of the 
medRxiv preprint doi: https://doi.org/10.1101/2022.02.09.22270682; this version posted February 10, 2022. The copyright holder for this preprint (which was not certified by peer review) is the author/funder, who has granted medRxiv a license to display the preprint in perpetuity. It is made available under a CC-BY-NC-ND 4.0 International license .

Kent - 9

neuroimaging reports. ${ }^{14}$ After two rounds of training, this NLP algorithm ultimately achieved F-scores of 0.93 and 0.92 in $\mathrm{CBI}$ and WMD.

\section{Follow-up}

Follow-up started 60 days after the index scan and ended with the earliest of the following events: disenrollment from the health plan, end of the study (December 31, 2019), death, or dementia (outcome). The 60-day window after the index scan was selected to further exclude patients with symptoms of cognitive decline that might have prompted the neuroimaging scan.

\section{Outcome definition}

The primary outcome of this study was dementia. The occurrence of dementia was defined by the following ICD-9 diagnosis codes: 290.x, 291.2, 292.82, 294.1x, 294.2x, or 331.0. Only a single code was required if accompanied by a cognitive enhancement medication dispensation, or any two codes on different dates (with the second as the event date) if cognitive enhancement medication was not dispensed. Equivalent ICD-9 and ICD-10 codes used and qualifying cognitive enhancement medications are shown

\section{in Supplement A2.}

\section{Statistical Analysis}

Kaplan-Meier plots were used to present dementia-free survival in patients with and without $\mathrm{CBI}$ and with and without WMD, with differences assessed by the log-rank test. The overall and risk-factor stratified crude incidence rates and the $95 \%$ confidence intervals $(\mathrm{Cl})$ were calculated using Poisson regression and reported as per 1,000 person-years of follow-up time. We examined the crude and adjusted associations of $\mathrm{CBI}$ and of WMD with dementia, using Cox proportional hazards regression models. For 
medRxiv preprint doi: https://doi.org/10.1101/2022.02.09.22270682; this version posted February 10, 2022. The copyright holder for this preprint

(which was not certified by peer review) is the author/funder, who has granted medRxiv a license to display the preprint in perpetuity.

It is made available under a CC-BY-NC-ND 4.0 International license .

Kent - 10

adjusted effects, we included known cardiovascular risk factors for stroke based on prediction models in the literature, including the following covariates: age, sex, race (non-Hispanic white; Asian/Pacific Islander; African American; Hispanic;

Multiple/other/unknown), diabetes, hypercholesterolemia, history of smoking, mean systolic blood pressure (averaged over prior year, excluding extreme values $<70$ or $>$ 200 to avoid including measurements from periods of critical illness), atrial fibrillation, carotid disease, congestive heart failure, peripheral arterial disease, and use of antiplatelet or statin therapy. ${ }^{17,18}$ We also included dementia risk factors, including presence of depression, body mass index, and exercise. ${ }^{19-22}$

For each risk factor, the proportional hazards assumption was examined by the Schoenfeld residuals test. Interaction terms were selected based on clinical judgement. In particular, we hypothesized that the effects of WMD and CBI would vary based on imaging modality. We thus compared the effect of the presence versus the absence of CBI or WMD separately in those examined by CT and by MRI. We also anticipated that these lesions might have greater prognostic importance in younger versus older patients and so included interactions with age ( $<$ age 70 versus $\geq$ age 70 ).

\section{Sensitivity Analysis}

Three sensitivity analyses were performed: 1) defining the outcome based on a single dementia diagnostic code [to examine the stability of results when a more sensitive outcome definition is used]; 2) excluding patients who were either on an antithrombotic at baseline or who had a clinical indication for antithrombotic therapy [to examine effects among an antithrombotic free population who might be considered appropriate for a trial testing "secondary prevention" with an antiplatelet agent]; 3) starting follow up 1-year 
medRxiv preprint doi: https://doi.org/10.1101/2022.02.09.22270682; this version posted February 10, 2022. The copyright holder for this preprint

(which was not certified by peer review) is the author/funder, who has granted medRxiv a license to display the preprint in perpetuity.

It is made available under a CC-BY-NC-ND 4.0 International license .

Kent - 11

after the index scan (instead of 60-days after the scan) [to rule out with greater certainty that the index scan was not ordered because of a suspected diagnosis of cognitive decline or dementia].

\section{Analysis of WMD grade}

To further stratify risk of dementia, we classified patients according to WMD severity using NLP, as discussed in Supplement A3. Using the description in neuroradiology reports, patients with WMD were classified into three severity grades: mild, moderate, or severe. Scan reports with insufficient information on severity were classified as "undetermined." Analyses were performed in a similar fashion to the main analysis described above. However, WMD severity was interacted with imaging modality and thus treated as 10 different classes (i.e., no WMD, mild WMD, moderate WMD, severe WMD, and undetermined WMD for CT and for MRI). The reference class for all hazards was those patients who underwent MRI imaging and were found to be free of WMD (i.e., the lowest risk group). We underscore that this approach, using a common reference class, is distinct from the main analysis which contrasted dementia hazards for patients with and without CCD for each modality separately (e.g., comparing hazards for dementia among patients with versus without WMD among those undergoing CT and separately among those undergoing MRI, using different reference classes for these contrasts).

Analyses were performed using SAS (Version 9.4 for Unix; SAS Institute, Cary, NC) and R Version 3.6.0 (R Foundation, Vienna, Austria).

\section{RESULTS}


medRxiv preprint doi: https://doi.org/10.1101/2022.02.09.22270682; this version posted February 10, 2022. The copyright holder for this preprint (which was not certified by peer review) is the author/funder, who has granted medRxiv a license to display the preprint in perpetuity. It is made available under a CC-BY-NC-ND 4.0 International license .

Kent - 12

A total of 241,050 individuals receiving brain neuroimaging, with a total of $1,049,777$ person-years of follow up time, were included in our analysis cohort (Supplement B, eFigure 1).

The median follow-up time was 3.73 years (range of 61 days to 10.83 years; interquartile range [IQR] 1.61 to 6.85 years). 62,479 (25.9\%) patients received MRI and 178,572 (74.1\%) received CT scan. CCD was identified in 74,975 (31.1\%) including $11,328(4.7 \%)$ with $\mathrm{CBI}$ and $69,931(29.0 \%)$ with WMD. There were 11,554 cases of dementia identified in follow-up, with a median time to event among those with dementia of 2.95 (IQR: 1.40 to 5.16 ) years. Table 1 describes patient characteristics in the total cohort and in those with CBI (regardless of WMD) and those with WMD (regardless of $\mathrm{CBI})$.

The crude dementia incidence rates (per 1,000 person-years) were 29.4 (95\% Cl 27.9 to 31.0 ) in patients with incidentally-discovered $\mathrm{CBI}$ and 23.5 (22.90 to 24.0$)$ for patients with WMD. This compares to an incidence rate of only 6.0 (5.8 to 6.2) in patients free of cerebrovascular disease (Table 2).

Dementia-free survival in those with and without CBI with and without WMD, stratified by modality (CT versus MRI), are shown in Figure $\mathbf{1 a}$ and $\mathbf{1 b}$, respectively. These graphs display clearly the higher incidence rates in patients with CCD detected by CT compared to MRI. In patients with $\mathrm{CBI}$, when detected by $\mathrm{CT}$, the annualized incidence rate was 32.8 (31.0 to 34.5$)$, whereas with MRI the incidence was 16.6 (14.2 to 19.3). In patients with WMD, when detected by CT, the annualized incidence rate was 37.7 (36.7 to 38.7), whereas with MRI the incidence was 9.6 (9.1 to 10.1). Overall, the crude 
medRxiv preprint doi: https://doi.org/10.1101/2022.02.09.22270682; this version posted February 10, 2022. The copyright holder for this preprint

(which was not certified by peer review) is the author/funder, who has granted medRxiv a license to display the preprint in perpetuity.

It is made available under a CC-BY-NC-ND 4.0 International license .

Kent - 13

hazard ratio (HR) for dementia associated with WMD was 3.72 (3.58 to 3.86); and with CBI was 2.91 (2.75 to 3.07) (Table 3).

In a multivariable model controlling for major cardiovascular and dementia risk factors, we examined the effect of WMD on dementia risk. Among patients undergoing CT scan, the adjusted HR for the presence versus the absence of WMD was 2.87 (2.58 to 3.19) for those < age 70 and 1.87 (1.79 to 1.95 ) for those $\geq$ age 70 . Among patients undergoing MRI, the adjusted HR for the presence versus the absence of WMD was 2.28 (1.99 to 2.62 ) for those < age 70 and 1.48 (1.32 to 1.66$)$ for those $\geq$ age 70 . The adjusted $\mathrm{HR}$ associated with $\mathrm{CBI}$ was 2.02 (1.70 to 2.41) for patients age $<70$ and 1.22 (1.15 to 1.30$)$ for patients age $\geq 70$ regardless of modality.

Supplement B, eTable 1 shows the crude and adjusted effects of other risk factors included in our model. In general, the predictive effects of all cardiovascular and dementia risk factors were in the expected direction in the multivariable model. Patients on statins or antiplatelet agents at the time of the index scan had crudely higher risks of dementia, presumably due to confounding by indication, but these effects were nullified after full adjustment.

\section{Sensitivity Analyses}

Dementia incidence patterns were largely the same across sensitivity analyses with a roughly uniform relative increase in outcome rates when dementia was established with only a single diagnostic code (Supplement B, eTable 2): 35.2 (95\% Cl: 33.5 to 36.9 ) per 1,000 person-years for patients with $\mathrm{CBI} ; 27.9$ (27.3 to 28.6) for patients with WMD 
medRxiv preprint doi: https://doi.org/10.1101/2022.02.09.22270682; this version posted February 10, 2022. The copyright holder for this preprint (which was not certified by peer review) is the author/funder, who has granted medRxiv a license to display the preprint in perpetuity. It is made available under a CC-BY-NC-ND 4.0 International license .

Kent - 14

and 7.3 (7.1 to 7.5$)$ for patients without CBI or WMD. Patients without any indications for antithrombotic therapy had overall lower dementia incidence than the full cohort: 23.8 (22.1 to 25.5$)$ per 1,000 person-years in those with $\mathrm{CBI} ; 18.4$ (17.8 to 19.0) for those with WMD; and 4.6 (4.5 to 4.8) for those without CCD (Supplement B, eTable 3). Neither incidence rates (Supplement B, eTable 4) nor HRs (Supplement B, eTable 5) changed substantially when follow-up started from 1 year post index scan rather than 60 days.

\section{Analysis of WMD grade}

As shown in Supplement B, eTable 6, among patients imaged by CT scan, $21 \%$ (36903/178571) were found to have WMD. Of these, $55 \%$ had mild disease, $10 \%$ had moderate disease, and $5 \%$ had severe disease; severity was "undetermined" for the remaining $30 \%$ of patients. Among patients imaged by MRI, 53\% (33028/62479) were found to have WMD. Of these, $62 \%$ had mild disease, $15 \%$ had moderate disease and $5 \%$ had severe disease; severity was underdetermined in the remaining $17 \%$ of patients. Within each imaging modality, the incidence of dementia increased monotonically in the expected direction among those with no, mild, moderate and severe disease. However, as shown in Figure 2 and Supplement B, eTable 6 the incidence was substantially higher among those imaged by CT. Incidence ranged from $3.1(95 \% \mathrm{Cl} 2.8$ to 3.4$)$ per 1,000 person years among those who were WMD negative by MRI to 64.1 (58.3 to 70.4 ) per 1,000 person years for those with severe WMD as detected by CT scan. Patients with mild disease by CT scan had a similar incidence of dementia to those with severe disease on MRI. Adjusted HRs compared to patients who 
were negative for WMD by MRI ranged from 1.41 (1.25 to 1.60) for those with mild disease on MRI to 4.11 (3.58 to 4.72) for those with severe disease on CT scan (Supplement B, eTable 6).

\section{DISCUSSION}

In this large observational cohort with approximately 250,000 subjects and over one million person-years of follow-up, we found that the presence of incidentally-discovered, NLP-identified CCD was strongly associated with an increased risk of future dementia. In patients between 50 and 70 years of age, $\mathrm{CBI}$ conferred a two-fold increased risk, after adjustment for other risk factors. On CT scan, patients with WMD had an adjusted risk almost three-fold that of those without WMD on CT scan; with MRI, the adjusted risk associated with WMD was approximately two-fold. These risk estimates are comparable to or greater than those for other major risk factors for dementia, including symptomatic ischemic stroke. ${ }^{23-26}$ While there remains some uncertainty regarding the potential heterogeneity of pathophysiology underlying CCD, these results support an interpretation of incidentally-discovered CBI or WMD as "stroke equivalents," at least with regards to risk of dementia. The size of these effects was reduced in patients $70_{+}$ years of age, emphasizing the importance of early identification and the need for effective mid-life prevention strategies. These findings establish that routinely obtained neuroimaging reports carry substantial information that can be used to identify patients at high risk of progressing to dementia.

To our knowledge, this is the first cohort on which the prognostic significance of incidentally-discovered CCD with regard to future dementia has been studied. A prior 
medRxiv preprint doi: https://doi.org/10.1101/2022.02.09.22270682; this version posted February 10, 2022. The copyright holder for this preprint

(which was not certified by peer review) is the author/funder, who has granted medRxiv a license to display the preprint in perpetuity.

It is made available under a CC-BY-NC-ND 4.0 International license .

Kent - 16

study in this cohort found that CBI was a "stroke equivalent" in terms of the risk of future clinically evident stroke. ${ }^{27}$ While the findings here are similar to some studies in screened cohorts, ${ }^{3,28}$ there are additional insights not previously known. In particular, we found a dramatic increase in the incidence of dementia following CT-detected CCD compared to MRI-detected CCD. The incidence of dementia was two-fold higher when $\mathrm{CBI}$ was detected by CT scan versus MRI and four-fold higher when WMD was detected by CT scan versus MRI (Table 2). The difference in risk is presumably due to the lower sensitivity of CT scan, particularly for WMD. Thus, when changes are detected with CT scan, CCD is generally more advanced. This is consistent with our prior findings in this cohort of a much lower age-related incidence of WMD in patients imaged by CT scanning compared to MRI. ${ }^{29}$

Importantly, in $77 \%$ of patients with WMD, we were able to extract prognosticallyinformative disease severity information from routinely obtained neuroimaging reports, which underscored the difference between CT- and MRI- detected WMD. The cohort of patients without WMD by CT scan appears to have similar risk of dementia as compared to patients with mild WMD on MRI, presumably due in part to the presence of undetected WMD within the CT scan cohort. And patients with mild WMD on CT scan have a risk of dementia similar to or greater than those with severe WMD by MRI. Patients with severe WMD on CT have a dementia incidence approximately 20 -fold higher than patients free of WMD on MRI, with an adjusted hazard ratio of 4 , indicating that neuroimaging reports contain substantial information useful for risk stratification. Patients with incidentally-discovered CCD may be an attractive target for dementia prevention for several reasons. First, the overall incidence of dementia in these patients 
medRxiv preprint doi: https://doi.org/10.1101/2022.02.09.22270682; this version posted February 10, 2022. The copyright holder for this preprint

(which was not certified by peer review) is the author/funder, who has granted medRxiv a license to display the preprint in perpetuity.

It is made available under a CC-BY-NC-ND 4.0 International license .

Kent - 17

is high, well over $2 \%$ per year in the current study, which makes it a feasible outcome for a prevention trial. Second, it identifies patients with an elevated risk of dementias attributed to vascular risk factors for which there are already many known effective therapies. Third, the number of patients with CCD appears to be abundant and now identifiable: we found over 11,000 patients aged $50+$ years of age with $\mathrm{CBI}$ and approximately 70,000 with WMD without prior symptomatic stroke or cognitive decline, including dementia, in a single health system, suggesting that neuroimaging reports might be a repository of a large number of high-risk patients suitable for trial enrollment. While prevention strategies for dementia are lacking, therapies used for secondary stroke prevention are attractive candidate interventions in this population, given the vascular contributions to the development of many dementias. And, in turn, this population may be an attractive high risk population for a trial. Antiplatelet medications have not previously been shown to be beneficial for prevention of dementia in a general population, but, in theory, may be helpful for patients with vascular brain injury (e.g. CCD). ${ }^{30}$ In this study, few patients were on prescribed antiplatelets ( $\left.5 \%\right)$, an unknown percentage were on over-the-counter aspirin, and about one-third had other indications for antithrombotic therapy. Given the size of this cohort, it is likely that a large population of patients may be candidates for randomization to antiplatelets in a clinical trial. Similarly, only half of the patients in this cohort were on statins. Finally, besides age, hypertension remains the most consistently shared risk factor between CCD, symptomatic stroke, and dementia, making it a compelling target for intervention among patients with incidentally-discovered CCD. ${ }^{31-35}$ Novel agents currently being studied in 
medRxiv preprint doi: https://doi.org/10.1101/2022.02.09.22270682; this version posted February 10, 2022. The copyright holder for this preprint

(which was not certified by peer review) is the author/funder, who has granted medRxiv a license to display the preprint in perpetuity.

It is made available under a CC-BY-NC-ND 4.0 International license .

Kent - 18

stroke prevention may have unique benefits or a different risk-benefit balance with

incidentally-discovered CCD. ${ }^{36,37}$

There are limitations to this study and the proposed approach to patient identification.

Patients were selected into this cohort because they had clinically-indicated

neuroimaging scans. Thus, the patients are not representative of the full spectrum of

patients with WMD and CBI. Additionally, as these reports were obtained from routine

care across multiple, heterogeneous clinical settings, there may be substantial

limitations to the consistency of and the degree of details recoverable from these

reports.

On the other hand, the use of routinely obtained neuroimaging reports as our source of data may also be viewed as the chief strength of our study. First, in the absence of population screening for CCD, incidentally-discovered CCD represents the most clinically relevant population. Further, by using reports obtained as part of routine care, we were able to estimate the prognostic value of imaging findings across diverse settings using heterogeneous imaging modalities without precise and standardized definitions of $\mathrm{CBI}$ and WMD, demonstrating the usefulness of routinely-obtained neuroimage reports. Interestingly, while MRI would be considered the gold standard to screen for CCD, CT scans comprised the majority of neuroimages included in our study; lesions discovered by CT scan appear to be substantially more prognostic than those discovered by MRI. Finally, unlike with artificial intelligence-driven direct analysis of neuroimages which may be subject to technical limitations of imaging data repositories (e.g., file size, transfer speed, cumbersome de-identification), we have demonstrated 
medRxiv preprint doi: https://doi.org/10.1101/2022.02.09.22270682; this version posted February 10, 2022. The copyright holder for this preprint

(which was not certified by peer review) is the author/funder, who has granted medRxiv a license to display the preprint in perpetuity.

It is made available under a CC-BY-NC-ND 4.0 International license .

Kent - 19

that neuroimaging reports are easily accessible and analyzable via NLP in the EHR of a large integrated health system.

\section{CONCLUSIONS}

Incidentally-discovered CCD including CBI and WMD are common and associated with a high risk for future dementia. Identification of patients with these conditions with an NLP algorithm on routinely-obtained neuroimaging reports may facilitate dementia prevention studies and risk stratification.

\section{ACKNOWLEDGEMENTS}

\section{Author Contributorship}

DMK contributed to conceptualization, funding acquisition, investigation, methodology, supervision, and wrote the original manuscript draft. YZ contributed to data curation, formal analysis, and investigation. LYL, PHL, DFK, and SF contributed to investigation and methodology. JN contributed to investigation. CZ contributed to data curation, investigation, and methodology. HL contributed to funding acquisition, investigation, methodology, and supervision. WC contributed to data curation, formal analysis, investigation, methodology, and supervision. All authors contributed equally to reviewing and editing the final manuscript.

\section{Data Availability Statement}

The datasets generated and/or analyzed during the current study are not publicly available due to ethical standards. The authors do not have permission to share data. Authors Wansu Chen and Yichen Zhou had full access to all the data in the study and take responsibility for the integrity of the data and the accuracy of the data analysis.

\section{Funding}


medRxiv preprint doi: https://doi.org/10.1101/2022.02.09.22270682; this version posted February 10, 2022. The copyright holder for this preprint

(which was not certified by peer review) is the author/funder, who has granted medRxiv a license to display the preprint in perpetuity. It is made available under a CC-BY-NC-ND 4.0 International license.

Kent - 20

This work was funded by a National Institutes of Health (NIH) grant (R01-NS102233).

The funder had no role in the design/conduct of the study, manuscript preparation, or decision to publish.

Competing Interests

The authors report no competing interests.

\section{Ethical Approval and Patient Consent}

This study was approved by the Tufts Health Sciences and KPSC Institutional Review

Board. Patient consent was not required as all data was anonymized. 
Kent - 21

\section{REFERENCES}

1. Livingston G, Huntley J, Sommerlad A, et al. Dementia prevention, intervention, and care: 2020 report of the Lancet Commission. Lancet (London, England). 2020;396(10248):413-446.

2. Langa KM, Foster NL, Larson EB. Mixed dementia: emerging concepts and therapeutic implications. JAMA. 2004;292(23):2901-2908.

3. Vermeer SE, Prins ND, den Heijer T, Hofman A, Koudstaal PJ, Breteler MM. Silent brain infarcts and the risk of dementia and cognitive decline. $N$ Engl J Med. 2003;348(13):1215-1222.

4. Sigurdsson S, Aspelund T, Kjartansson O, et al. Incidence of Brain Infarcts, Cognitive Change, and Risk of Dementia in the General Population: The AGESReykjavik Study (Age Gene/Environment Susceptibility-Reykjavik Study). Stroke. 2017;48(9):2353-2360.

5. Longstreth WT, Manolio TA, Arnold A, et al. Clinical correlates of white matter findings on cranial magnetic resonance imaging of 3301 elderly people. The Cardiovascular Health Study. Stroke. 1996;27(8):1274-1282.

6. Carmichael O, Schwarz C, Drucker D, et al. Longitudinal changes in white matter disease and cognition in the first year of the Alzheimer disease neuroimaging initiative. Arch Neurol. 2010;67(11):1370-1378.

7. Moghekar A, Kraut M, Elkins W, et al. Cerebral white matter disease is associated with Alzheimer pathology in a prospective cohort. Alzheimers Dement. 2012;8(5 Suppl):S71-77. 
8. $\quad$ Song IU, Kim JS, Kim YI, Eah KY, Lee KS. Clinical significance of silent cerebral infarctions in patients with Alzheimer disease. Cogn Behav Neurol. 2007;20(2):93-98.

9. Wright CB, Festa JR, Paik MC, et al. White matter hyperintensities and subclinical infarction: associations with psychomotor speed and cognitive flexibility. Stroke. 2008;39(3):800-805.

10. Liebetrau M, Steen B, Hamann GF, Skoog I. Silent and symptomatic infarcts on cranial computerized tomography in relation to dementia and mortality: a population-based study in 85-year-old subjects. Stroke. 2004;35(8):1816-1820.

11. Leung LY, Han PKJ, Lundquist C, Weinstein G, Thaler DE, Kent DM. Clinicians' perspectives on incidentally discovered silent brain infarcts - A qualitative study. PloS one. 2018;13(3):e0194971.

12. Leung LY, Han PKJ, Lundquist C, Weinstein G, Thaler D, E., Kent DM. Patients' responses to incidentally discovered silent brain infarcts - a qualitative study. $J$ Patient Rep Outcomes. 2019;3(1):23.

13. Smith EE, Saposnik G, Biessels GJ, et al. Prevention of Stroke in Patients With Silent Cerebrovascular Disease: A Scientific Statement for Healthcare Professionals From the American Heart Association/American Stroke Association. Stroke. 2017;48(2):e44-e71.

14. Fu S, Leung LY, Wang Y, et al. Natural Language Processing for the Identification of Silent Brain Infarcts From Neuroimaging Reports. JMIR Med Inform. 2019;7(2):e12109. 
15. Leung LY, Fu S, Luetmer PH, et al. Agreement between neuroimages and reports for natural language processing-based detection of silent brain infarcts and white matter disease. BMC Neurol. 2021;21:189.

16. Koebnick C, Langer-Gould AM, Gould MK, et al. Sociodemographic characteristics of members of a large, integrated health care system: comparison with US Census Bureau data. Perm J. 2012;16(3):37-41.

17. Flueckiger P, Longstreth W, Herrington D, Yeboah J. Revised Framingham Stroke Risk Score, Nontraditional Risk Markers, and Incident Stroke in a Multiethnic Cohort. Stroke. 2018;49(2):363-369.

18. Wolf PA, D'Agostino RB, Belanger AJ, Kannel WB. Probability of stroke: a risk profile from the Framingham Study. Stroke. 1991;22(3):312-318.

19. Yan S, Fu W, Wang C, et al. Association between sedentary behavior and the risk of dementia: a systematic review and meta-analysis. Transl Psychiatry. 2020;10(1):112.

20. Chan YE, Chen MH, Tsai SJ, et al. Treatment-Resistant depression enhances risks of dementia and alzheimer's disease: A nationwide longitudinal study. $J$ Affect Disord. 2020;274:806-812.

21. Barnes DE, Covinsky KE, Whitmer RA, Kuller LH, Lopez OL, Yaffe K. Dementia risk indices: A framework for identifying individuals with a high dementia risk. Alzheimers Dement. 2010;6(2):138-141.

22. Qizilbash N, Gregson J, Johnson ME, et al. BMI and risk of dementia in two million people over two decades: a retrospective cohort study. Lancet Diabetes Endocrinol. 2015;3(6):431-436. 
23. Zhou J, Yu JT, Wang HF, et al. Association between stroke and Alzheimer's disease: systematic review and meta-analysis. Journal of Alzheimer's disease : JAD. 2015;43(2):479-489.

24. Georgakis MK, Duering M, Wardlaw JM, Dichgans M. WMH and long-term outcomes in ischemic stroke: A systematic review and meta-analysis. Neurology. 2019;92(12):e1298-e1308.

25. Kuźma E, Lourida I, Moore SF, Levine DA, Ukoumunne OC, Llewellyn DJ. Stroke and dementia risk: A systematic review and meta-analysis. Alzheimers Dement. 2018;14(11):1416-1426.

26. Pendlebury ST, Rothwell PM. Prevalence, incidence, and factors associated with pre-stroke and post-stroke dementia: a systematic review and meta-analysis. Lancet Neurol. 2009;3(11):1006-1018.

27. Kent DM, Leung LY, Zhou Y, et al. Association of Silent Cerebrovascular Disease Identified Using Natural Language Processing and Future Ischemic Stroke. Neurology. 2021;97(13):e1313-1321.

28. Debette S, Markus HS. The clinical importance of white matter hyperintensities on brain magnetic resonance imaging: systematic review and meta-analysis. BMJ. 2010;341:c3666.

29. Leung LY, Zhou Y, Fu S, et al. Risk factors for silent brain infarcts and white matter disease in a real-world cohort identified by NLP. Mayo Clinic Proceedings. $2021 ;[$ In press]. 
30. Jordan F, Quinn TJ, McGuinness B, et al. Aspirin and other non-steroidal antiinflammatory drugs for the prevention of dementia. Cochrane Database Syst Rev. 2020;4(4):CD011459.

31. Williamson JD, Pajewski NM, Auchus AP, et al. Effect of Intensive vs Standard Blood Pressure Control on Probable Dementia: A Randomized Clinical Trial. JAMA. 2019;321(6):553-561.

32. Alosco ML, Sugarman MA, Besser LM, et al. A Clinicopathological Investigation of White Matter Hyperintensities and Alzheimer's Disease Neuropathology. $J$ Alzheimers Dis. 2018;63(4):1347-1360.

33. Gupta A, Giambrone AE, Gialdini G, et al. Silent Brain Infarction and Risk of Future Stroke: A Systematic Review and Meta-Analysis. Stroke. 2016;47(3):719725.

34. Fanning JP, Wong AA, Fraser JF. The epidemiology of silent brain infarction: a systematic review of population-based cohorts. BMC medicine. 2014;12:119.

35. Kuller LH, Longstreth WT, Arnold AM, et al. White matter hyperintensity on cranial magnetic resonance imaging: a predictor of stroke. Stroke. 2004;35(8):1821-1825.

36. Smith EE, Markus HS. New Treatment Approaches to Modify the Course of Cerebral Small Vessel Diseases. Stroke. 2020;51(1):38-46.

37. Bath PM, Wardlaw JM. Pharmacological treatment and prevention of cerebral small vessel disease: a review of potential interventions. Int $J$ Stroke. 2015;10(4):469-478. 


\section{FIGURES}

Figure 1: Kaplan-Meier plot of dementia-free survival with and without covert brain infarct (A) and with and without white matter disease $(B)$ stratified by imaging modality (CT versus MRI)

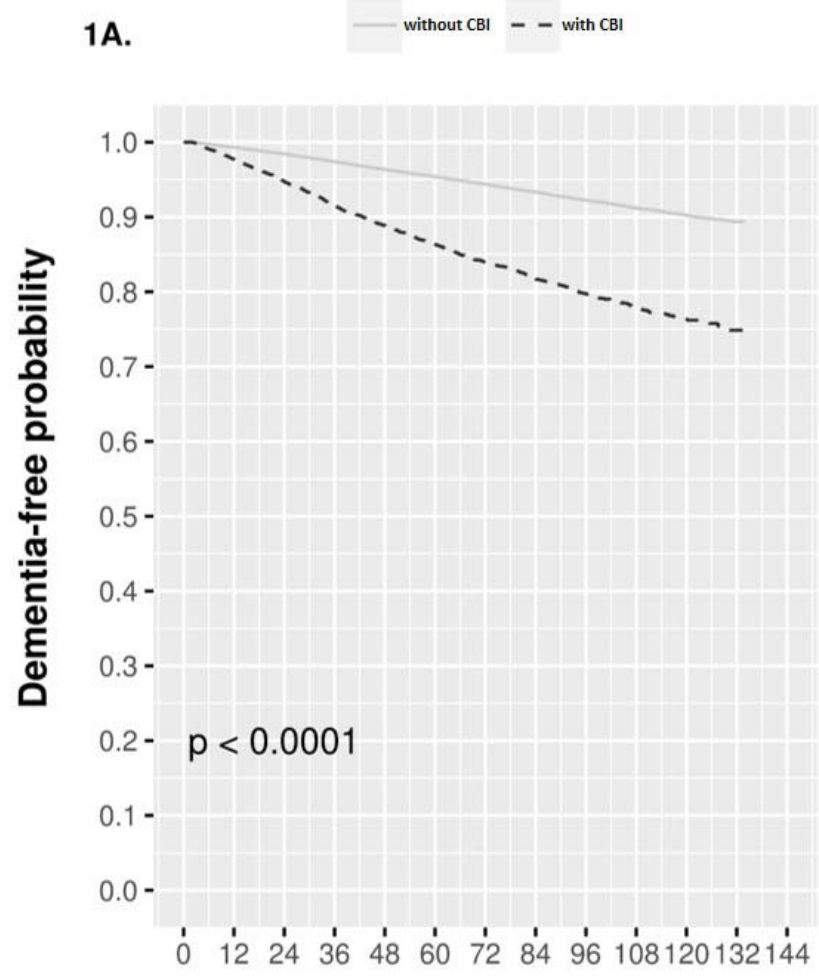

1B. $\quad$ without WMD - - with WMD

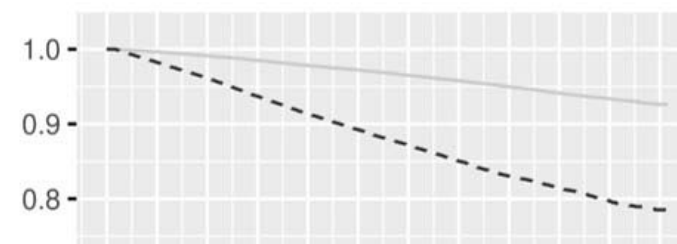

$0.7-$

$0.6-$

$0.5-$

$0.4-$

$0.3-$

$0.2-p<0.0001$

$0.1-$

$0.0-$

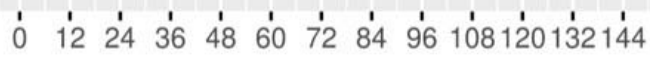

Months after image scan

Differences in dementia free survival were assessed by the log rank test.

CBI: Covert brain infarct; WMD: White matter disease; CT: Computed tomography; MR:

Magnetic resonance 
Kent - 27

Figure 2: Kaplan-Meier plot of dementia-free survival by modality and white matter disease severity grade

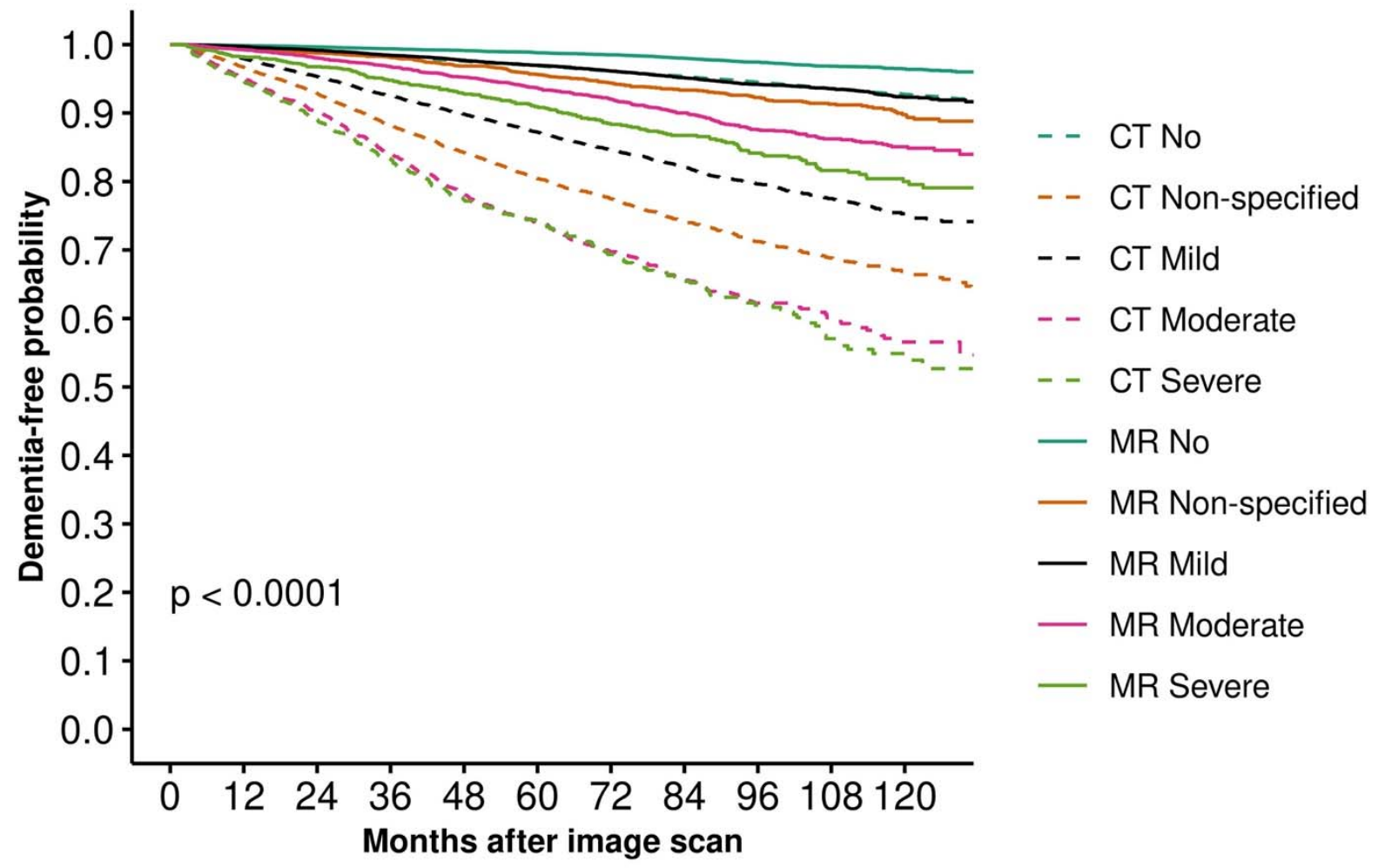

CT: Computed tomography; MR: Magnetic resonance 
medRxiv preprint doi: https://doi.org/10.1101/2022.02.09.22270682; this version posted February 10, 2022. The copyright holder for this preprint (which was not certified by peer review) is the author/funder, who has granted medRxiv a license to display the preprint in perpetuity. It is made available under a CC-BY-NC-ND 4.0 International license .

Kent - 28

\section{TABLES}

Table 1. Patient demographic and clinical characteristics at baseline

\begin{tabular}{|c|c|c|c|c|}
\hline Patient characteristics & Entire cohort & $\begin{array}{l}\text { Subset: } \\
\text { patients with } \\
\text { covert brain } \\
\text { infarction }\end{array}$ & $\begin{array}{l}\text { Subset: } \\
\text { patients with } \\
\text { white matter } \\
\text { disease }\end{array}$ & $\begin{array}{l}\text { Subset: } \\
\text { patients without } \\
\text { covert } \\
\text { cerebrovascular } \\
\text { disease }\end{array}$ \\
\hline $\mathrm{N}$ & 241,050 & 11,328 & 69,931 & 166,075 \\
\hline \multicolumn{5}{|l|}{ Demographics } \\
\hline Age, mean (SD) & $64.9(10.42)$ & $72.2(10.79)$ & 70.7 (10.77) & $62.3(9.17)$ \\
\hline Female & $147,812(61.3 \%)$ & $6,447(56.9 \%)$ & $42,659(61.0 \%)$ & $102,261(61.6 \%)$ \\
\hline \multicolumn{5}{|l|}{ Race/ ethnicity } \\
\hline Asian and Pacific Islander & $28,353(11.8 \%)$ & $1,256(11.1 \%)$ & $8,030(11.5 \%)$ & $19,755(11.9 \%)$ \\
\hline African American & $27,305(11.3 \%)$ & $1,643(14.5 \%)$ & $7,821(11.2 \%)$ & $18,745(11.3 \%)$ \\
\hline Hispanic & $78,146(32.4 \%)$ & $2,869(25.3 \%)$ & $17,419(24.9 \%)$ & $59,253(35.7 \%)$ \\
\hline Multiple/Other/Unknown & $3,999(1.7 \%)$ & $134(1.2 \%)$ & $990(1.4 \%)$ & $2,951(1.8 \%)$ \\
\hline Non-Hispanic white & $103,247(42.8 \%)$ & $5,426(47.9 \%)$ & $35,671(51.0 \%)$ & $65,371(39.4 \%)$ \\
\hline \multicolumn{5}{|l|}{ Stroke risk factors } \\
\hline Atrial fibrillation & $14,073(5.8 \%)$ & $1,314(11.6 \%)$ & $6,372(9.1 \%)$ & $7,247(4.4 \%)$ \\
\hline Carotid atherosclerosis & $2,312(1.0 \%)$ & $206(1.8 \%)$ & $1,125(1.6 \%)$ & $1,120(0.7 \%)$ \\
\hline Congestive heart failure & $11,450(4.8 \%)$ & $1,214(10.7 \%)$ & $5,228(7.5 \%)$ & $5,784(3.5 \%)$ \\
\hline Coronary artery disease & $25,793(10.7 \%)$ & $2,162(19.1 \%)$ & $10,324(14.8 \%)$ & $14,667(8.8 \%)$ \\
\hline Diabetes mellitus & $62,537(25.9 \%)$ & $3,995(35.3 \%)$ & $20,385(29.2 \%)$ & $40,479(24.4 \%)$ \\
\hline Hypercholesterolemia & $163,808(68.0 \%)$ & $8,505(75.1 \%)$ & $51,027(73.0 \%)$ & $109,089(65.7 \%)$ \\
\hline Hypertension & $145,536(60.4 \%)$ & $8,941(78.9 \%)$ & $49,759(71.2 \%)$ & $92,061(55.4 \%)$ \\
\hline Peripheral arterial disease & $10,539(4.4 \%)$ & $1,067(9.4 \%)$ & $4,749(6.8 \%)$ & $5,434(3.3 \%)$ \\
\hline Tobacco use (ever) & & & & \\
\hline
\end{tabular}


medRxiv preprint doi: https://doi.org/10.1101/2022.02.09.22270682; this version posted February 10, 2022. The copyright holder for this preprint (which was not certified by peer review) is the author/funder, who has granted medRxiv a license to display the preprint in perpetuity. It is made available under a CC-BY-NC-ND 4.0 International license.

Kent - 29

Yes

No

Unknown

Number of stroke risk

factors

Systolic blood pressure, mean

(SD)

Modality

CT

MRI

Antiplatelet use

Statin use

Depression

Exercise (hour/per week),

mean (SD)

BMI $\left(\mathrm{kg} / \mathrm{m}^{2}\right)$, mean (SD)

Covert brain infarction

White matter disease

Covert cerebrovascular

disease $^{a}$

$$
\begin{array}{r}
111,272(46.2 \%) \\
129,005(53.5 \%) \\
773(0.3 \%)
\end{array}
$$

$2.3(1.47)$

$2.9(1.59)$

$2.6(1.52)$

$2.1(1.42)$

$129.3(13.17)$

$132.7(13.85)$

$131.4(13.09)$

$128.4(13.07)$

$$
\begin{gathered}
178,571(74.1 \%) \\
62,479(25.9 \%)
\end{gathered}
$$

$9,041(79.8 \%)$

36,903 (52.8\%)

$137,121(82.6 \%)$

$2,287(20.2 \%)$

$33,028(47.2 \%)$

$28,954(17.4 \%)$

$10,986(4.6 \%)$

$753(6.7 \%)$

$3,928(5.6 \%)$

$6,763(4.1 \%)$

$103,572(43.0 \%)$

6,022 (53.2\%) 34,998 (50.1\%)

$66,023(39.8 \%)$

47,057 (19.5\%)

$2,189(19.3 \%) \quad 13,713(19.6 \%)$

$32,322(19.5 \%)$

1.7 (2.53)

1.5 (2.39)

$1.7(2.50)$

$1.8(2.54)$

28.7 (6.04)

27.9 (5.94)

$27.9(5.83)$

$29.0(6.09)$

$11,328(4.7 \%)$

NA $\quad 6,284(9.0 \%)$

$69,931(29.0 \%)$

$6,284(55.5 \%)$

NA

NA

NA

74,975 (31.1\%)

NA

NA

NA

SD-standard deviation

${ }^{a}$ Covert brain infarction or white matter disease 
Table 2. Dementia ${ }^{a}$ incidence rate overall and in subgroups $(n=241,050)$.

\begin{tabular}{|c|c|c|c|c|c|c|c|c|c|c|c|c|}
\hline \multirow[b]{2}{*}{$\begin{array}{l}\text { Patient } \\
\text { Characteristics }\end{array}$} & \multicolumn{3}{|c|}{$\begin{array}{l}\text { Patients with covert brain } \\
\text { infarction }(C B I)(n=11,328)\end{array}$} & \multicolumn{3}{|c|}{$\begin{array}{l}\text { Patient with white matter } \\
\text { disease (WMD) }(n=69,931)\end{array}$} & \multicolumn{3}{|c|}{$\begin{array}{c}\text { Patients with both CBI and WMD } \\
\text { disease }(n=6,284)\end{array}$} & \multicolumn{3}{|c|}{$\begin{array}{l}\text { Patients without CBI or WMD } \\
\qquad(n=166,075)\end{array}$} \\
\hline & $\begin{array}{c}\text { Avg } \\
\text { f/u, } \\
\text { yrs }\end{array}$ & $\begin{array}{r}\text { No. } \\
\text { events }\end{array}$ & $\begin{array}{r}\text { Incidence rate } \\
(95 \% \mathrm{Cl})\end{array}$ & $\begin{array}{l}\text { Avg } \\
\text { f/u, } \\
\text { yrs }\end{array}$ & $\begin{array}{r}\text { No. } \\
\text { events }\end{array}$ & $\begin{array}{r}\text { Incidence rate } \\
(95 \% \mathrm{Cl})\end{array}$ & $\begin{array}{c}\text { Avg } \\
\text { f/u, } \\
\text { yrs }\end{array}$ & $\begin{array}{r}\text { No. } \\
\text { events }\end{array}$ & $\begin{array}{r}\text { Incidence rate } \\
(95 \% \mathrm{Cl})\end{array}$ & $\begin{array}{l}\text { Avg } \\
\text { f/u, } \\
\text { yrs }\end{array}$ & $\begin{array}{r}\text { No. } \\
\text { events }\end{array}$ & $\begin{array}{r}\text { Incidence rate } \\
(95 \% \mathrm{Cl})\end{array}$ \\
\hline $\begin{array}{l}\text { All } \\
\text { Age group (yrs) }\end{array}$ & 4.28 & 1,425 & $29.4(27.9,31.0)$ & 4.08 & 6,697 & $23.5(22.9,24.0)$ & 3.89 & 1,016 & $41.5(39.0,44.1)$ & 4.46 & 4,448 & $6.0(5.8,6.2)$ \\
\hline $50-59$ & 4.61 & 24 & $3.0(2.0,4.4)$ & 4.40 & 57 & $1.0(0.8,1.3)$ & 4.40 & 10 & $4.3(2.1,7.9)$ & 4.43 & 167 & $0.5(0.4,0.6)$ \\
\hline $60-69$ & 4.68 & 115 & $8.2(6.8,9.8)$ & 4.33 & 559 & $6.4(5.9,6.9)$ & 4.29 & 70 & $11.9(9.4,14.9)$ & 4.55 & 849 & $3.5(3.3,3.7)$ \\
\hline $70-79$ & 4.50 & 484 & $29.3(26.8,32.0)$ & 4.16 & 2,436 & $27.1(26.0,28.1)$ & 4.16 & 325 & $34.9(31.3,38.9)$ & 4.57 & 1,882 & $16.3(15.5,17.0)$ \\
\hline $\begin{array}{l}80+ \\
\text { Sex }\end{array}$ & 3.39 & 802 & $80.3(74.9,86.0)$ & 3.33 & 3,645 & $73.1(70.7,75.5)$ & 3.24 & 611 & $87.6(80.8,94.7)$ & 3.87 & 1,550 & $49.4(47.0,51.9)$ \\
\hline Female & 4.49 & 876 & $30.3(28.3,32.3)$ & 4.19 & 4,339 & $24.3(23.6,25.0)$ & 4.08 & 619 & $42.7(39.5,46.2)$ & 4.56 & 2,868 & $6.1(5.9,6.4)$ \\
\hline $\begin{array}{l}\text { Male } \\
\text { Race/ ethnicity }\end{array}$ & 4.00 & 549 & $28.1(25.9,30.6)$ & 3.91 & 2,358 & $22.1(21.2,23.0)$ & 3.66 & 397 & $39.7(36.0,43.8)$ & 4.30 & 1,580 & $5.8(5.5,6.1)$ \\
\hline Non-Hisp. white & 4.19 & 752 & $33.0(30.7,35.5)$ & 4.09 & 3,778 & $25.9(25.1,26.7)$ & 3.85 & 567 & $45.8(42.1,49.7)$ & 4.53 & 2,176 & $7.3(7.0,7.7)$ \\
\hline Asian/PI & 4.59 & 114 & $19.8(16.4,23.6)$ & 4.26 & 555 & $16.2(14.9,17.6)$ & 4.10 & 74 & $26.2(20.7,32.7)$ & 4.70 & 382 & $4.1(3.7,4.5)$ \\
\hline African Am. & 4.39 & 255 & $35.4(31.2,39.9)$ & 4.13 & 928 & $28.8(26.9,30.6)$ & 3.90 & 175 & $49.7(42.7,57.5)$ & 4.73 & 634 & $7.2(6.6,7.7)$ \\
\hline
\end{tabular}


Kent - 31

\begin{tabular}{|c|c|c|c|c|c|c|c|c|c|c|c|c|}
\hline Hispanic & 4.28 & 293 & $23.9(21.3,26.7)$ & 3.99 & 1,393 & $20.0(19.0,21.1)$ & 3.97 & 195 & $35.2(30.5,40.4)$ & 4.26 & 1,218 & $4.8(4.6,5.1)$ \\
\hline Other $^{\mathrm{b}}$ & 3.20 & 11 & $25.7(13.6,44.4)$ & 3.31 & 43 & $13.1(9.6,17.5)$ & 2.66 & 5 & $24.7(8.0,57.6)$ & 3.55 & 38 & $3.6(2.6,4.9)$ \\
\hline \multicolumn{13}{|c|}{ Imaging Modality } \\
\hline CT & 4.25 & 1,258 & $32.8(31.0,34.6)$ & 3.81 & 5,307 & $37.7(36.7,38.7)$ & 3.76 & 871 & $51.6(48.3,55.1)$ & 4.46 & 4,067 & $6.7(6.5,6.9)$ \\
\hline MRI & 4.40 & 167 & $16.6(14.2,19.3)$ & 4.37 & 1,390 & $9.6(9.1,10.1)$ & 4.24 & 145 & $19.1(16.2,22.4)$ & 4.47 & 381 & $2.9(2.7,3.3)$ \\
\hline
\end{tabular}

CBI-covert brain infarction; WMD-white matter disease; PI-Pacific islander

aDementia was defined by two ICD diagnostic codes or one diagnostic code and one medication dispensing.

${ }^{\mathrm{b}}$ Multiple, other or unknown race/ethnicity. 
Kent - 32

Table 3. Crude and adjusted hazard ratios (HRs) for dementia by covert brain infarction (CBI) and white matter disease (WMD)

\begin{tabular}{|lrr|}
\hline \multicolumn{1}{|c|}{ HR } & $95 \% \mathrm{Cl}$ \\
Crude & & \\
WMI & 2.91 & $(2.75,3.07)$ \\
\hline Adjusted (varied by age and modality) \\
CBI & 3.72 & $(3.58,3.86)$ \\
Age $<70$ years & 2.02 & $(1.70,2.41)$ \\
Age $\geq 70$ years & 1.22 & $(1.15,1.30)$ \\
WMD & & \\
MRI, age $<70$ & 2.28 & $(1.99,2.62)$ \\
MRI, age $\geq 70$ & 1.48 & $(1.32,1.66)$ \\
CT, age $<70$ & 2.87 & $(2.58,3.19)$ \\
CT, age $\geq 70$ & 1.87 & $(1.79,1.95)$ \\
\end{tabular}

HR-hazard ratio; CBI-covert brain infarction; WMD-white matter disease; MRI-magnetic resonance imaging; CT-computerized tomography

The multivariable model included age, sex, race/ethnicity, atrial fibrillation, carotid atherosclerosis, congestive heart failure, coronary artery disease, diabetes mellitus, hypercholesterolemia, hypertension, peripheral arterial disease, ever tobacco use, mean systolic blood pressure in one year, antiplatelet use, stain use, depression, exercise (hour/per week), BMI $\left(\mathrm{kg} / \mathrm{m}^{2}\right)$, modality, age ${ }^{\star} \mathrm{CBI}$, age ${ }^{\star} \mathrm{WMD}$, and modality*WMD. Refer to Supplement B, eTable 1 for HRs of all the covariates. 